\title{
The Character Education Through the Symbolic Meaning of Javanese Puppets
}

\author{
Sulistiyani, Dewi Rosaria Indah \\ Departement of English Language Education \\ STKIP BIM \\ Surabaya, Indonesia \\ sulistiyani@stkipbim.ac.id
}

\author{
Soedjarwo \\ Departement of Non-Formal Education \\ Universitas Negeri Surabaya \\ Surabaya, Indonesia
}

\begin{abstract}
This study aims to examine character education implemented in character education taken through imaging the figures of clowns in Javanese puppetry in order to enhance the values in character education of students in the world of education through symbolic meaning. This research was conducted because the authors are due to see education and quality is declining today. In this study, humans play an important role as an instrument to be the main data collection tool in the form of observations, interviews, or document studies. The results of this study can be formulated that symbolic figures of Javanese puppets in Javanese puppet that meanings are studies of Javanese puppet values as a servant who has an exemplary attitude (honesty, fairness, not giving up / despairing, and a high sense of nationalism) that is very necessary and implied in the value of character education. Character education in the subject of character education according to the constructivism theory approach for students, especially STKIP Bina Insan Mandiri Surabaya students emphasizes individual development in cognitive, affective, and psychomotor abilities so that they can create a generation that is of good quality in terms of intellectual, personality and character in future.
\end{abstract}

Keywords-character education; symbolic meaning; javanese puppet

\section{INTRODUCTION}

The development of education carried out in Indonesia needs to pay attention to the concept of learning and learning. In this era of globalization, it illustrates a turning point in the development of human civilization that is increasingly intense. This is indicated by the growth of awareness of values. Even for the scientific field which was once considered to be valuefree, today there are many positions and roles of value.

Many school graduates and scholars who are clever in answering exam questions, are intelligent, but mentally weak, timid, and behavior is not commendable and do actions that are contrary to character. With the existence of image and symbol theory in the way the author conducts analysis to examine the imaging value of clown man who later obtained the meaning of life with the constructivism theory approach of the clown in Javanese puppets.

Cultural education and national character are very vigorously carried out in the world of education because it aims to prepare students to become better citizens, namely citizens who have the ability, willingness, and apply the values of
Pancasila in their lives as Indonesian citizens and develop into a theoretical approach constructivism where students appreciate the ideas or thoughts of other students and encourage students to think independently, in finding their own intellectual identity and being problem solver problem solvers.

This proves that education without character and character has been considered to fail to educate the nation's learners. This study uses interpretive descriptive methods and literature using the theory of Javanese puppets symbol imagery and constructivism theory. The research used in this study has the purpose of understanding the phenomena experienced by the research subject. Through this research, descriptive data collected is in the form of words and symbols.

Related to the role of value, character education should bring learners to cognitive value recognition, affective value appreciation, and ultimately to actual value practices associated with approaches to constructivism theory. The nature of constructivism learning theory is to develop students' activeness in constructing their own knowledge, so that with the knowledge they have students can better interpreted the value of learning. This is because it is related to the initial conception that students have and the experience students get. So that the meaning of learning according to constructivism can be interpreted as active activity, where the students develop their own knowledge, look for the meaning of what they learn and is the process of completing concepts and exploring new ideas that are better with existing frameworks of thought and possessions [1]. From the description of the definition of constructivism theory, it makes the writer feel more inclined to interpret it. The author thinks that constructive theory is a theory that brings a considerable response in self-improvement or in other words this theory is very well used in improving character education.

The current problem of character education needs to get a response that is so great considering that the morale of the nation is getting more damaged, alternative solutions must be ought immediately and it needs to be developed more operationally so that it is easy to implement. Character education is education that prioritizes in terms of understanding and sensitivity that are wrapped in character that always involves aspects of knowledge, feelings, and actions. So, with character education, an individual can be emotionally intelligent. Emotional intelligence is also a very important provision to meet life in the future. Podhorsky \& Moore [2] 
states that education should be interpreted as an effort to create programs which include values that focus on improving teaching and learning practices, not solely focusing on designing classes with teacher proof curriculum. This value has also been applied to every packaged science study through the curriculum. The 2013 revised curriculum that is currently developing has given proportional attention to the dimensions of cognitive, effective, and psychomotor.

Speaking of values, values have a relationship that is closely related to culture. There are three forms of culture, namely: (a) the form of culture as a complex of ideas, ideas, values, norms, and regulations; (b) the form of culture as a complex pattern of activities and actions from within the community; (c) the form of culture as objects produced by humans [3]. Bina Insan Mandiri Surabaya College of Teacher Training and Education (STKIP BIM) is a formal educational institution at the university level. Graduates from STKIP BIM become graduates of education whose main task is to educate the sons and daughters of the nation to always do truth, goodness, and beauty. Implementation in the implementation of values whose success can be estimated from a number of behaviors on a particular value topic.

Based on the above problems, the author wants to conduct research activities by combining approaches to the learning process with symbolic meaning in value imaging that leads to character education. The research activity was discribing: Symbolic Meaning "Punakawan Javanese puppet" (A Value Imaging Study in Character Education on Courses)

\section{METHOD}

In this study, researchers used qualitative research methods with a descriptive qualitative approach. According to Moleong [4], qualitative research is a research that has the intention to understand what phenomena are experienced by research subjects. Through this qualitative research, descriptive data collected in the form of words, images, and not numbers [5]. In qualitative research, humans play important roles as instruments. In conducting research, researchers themselves are the main data collection tools in the form of observations, interviews, or document review.

The data in this study were collected by natural settings on the performance of puppet shows with various respondents such as puppeteers, sinden, rapper, talent and puppet crew, to describe the image of values in character education from symbolic meanings in Javanese puppet characters in the subject of character education especially in environment of STKIP Bina Insan Mandiri Surabaya. When viewed from the data source, the following data collection is in the form of words that will be compiled in a narrative and in the form of images in the form of symbols, where this will be able to clarify and strengthen the data obtained previously. Furthermore, when viewed in terms of methods or techniques of data collection, researchers used the method of observation, interviews, and documentation.

In qualitative research, making notes is indeed necessary to use as an ingredient in making data analysis. Making notes can be done when conducting interviews or even while still conducting interviews and observations [6]. Documentation comes from the word document which means written goods. Using the documentation method means collecting data by recording existing data. According to Yin [5] said that the document is a record of events that have passed. Documents can be in the form of writing, images, or works from someone. So, it is clear the existence of symbolic meanings in the imaging of values in character education in Javanese puppets, especially in the environment of STKIP Bina Insan Mandiri Surabaya as an implementation of the subject of character education.

To test the validity of the data in this study using an extension of observation and triangulation to test the validity of the data obtained from the study. In order to obtain complete data in the performance. So that it has a very clear symbolic meaning in imaging values in character education in Javanese puppet experts, especially in the environment of STKIP Bina Insan Mandiri Surabaya as an implementation of the subject of character education.

Moleong [4] explained that in carrying out data analysis, of course, the process of data collection in the field through field notes, reading or studying data, gathering, sorting, and then thinking by making the data category so that can have symbolic meanings in imaging values in character education in Javanese puppet experts, especially in the environment of STKIP Bina Insan Mandiri Surabaya as an implementation of the subject of character education.

Character Education in STKIP Bina Insan Mandiri. The theory of imaging symbols according to Risdiyanti and Prahmana [7] symbols or symbols in Javanese culture is a reference for behaving and has a function as a guide that gives direction to the experience of human life. This is a study of value imaging that has complex meanings in character education. Character education is generally summarized in the subjects of character combined with approaches from constructivism theory. According to Vygotsky, students carry out learning activities through interaction with adults and peers who have more abilities.

\section{RESULTS AND DISCUSSION}

\section{A. Punakawan in Puppet}

In puppet art, there are many life stories presented. The puppet art connoisseurs must be familiar with life stories taken from these ancient literary works, ranging from the Ramayana story to the Mahabarata. Not only that, every puppet shows must also have a moral message to be conveyed by a puppeteer. The puppeteer is the person who plays the puppet show in a show. Likewise, with the four puppet characters who were packaged into pirates in Javanese puppets.

The Punakawan are shown as funny cheerful groups with their typical humor to melt the atmosphere. In addition, Punakawan also has their own character which is certainly worth exploring deeper into each character presented and also giving a good effect in value attitute for all people at the implementation of life [8].

- Semar 
Semar is one of the characters who is always present in Punakawan, he is told as the main character servant of the story Sahadewa from the Pandawa family. The head and view of Semar always face upwards. This actually contains a philosophy that describes human life in order to always remember the Almighty (God). This figure is so good for giving the example of life especially which has correlation with moral attitute in life in STKIP BIM. Because Semar was so kind and he was low profile. The cloth that was used as a shirt by Semar, namely the Semangkusumorojo patterned Semar which is an embodiment, in order to worship the banowo or always uphold justice and truth on earth. In Javanese, spiritual circles, Semar is considered a symbol of the Oneness.

\section{- Gareng}

Gareng in Javanese puppet stories is an adopted child from Semar. Gareng has one limp leg. This teaches philosophy in life so that it is always careful when acting and behaving. In a story, Gareng in his previous history was a king, but because of his arrogance, he challenged every knight who came to see him and every time in a fight, they were always balanced. Gareng, who has a short stature, always walks down his gaze. This indicates caution in behaving and behaving.

\section{- Petruk}

Petruk is usually portrayed as a person who likes to joke and joke, both through speech and behavior. As a clown man, Petruk is a person who can nurture, can keep things a secret, always be a good listener, and always benefit others. Petruk was so kind. This figure is so good for giving the example of life especially which has correlation with moral attitude in life in STKIP BIM

\section{- Bagong}

Bagong's figure is depicted as short, fat, but his eyes and mouth are so wide, which depicts his presumptuous yet honest and powerful character. This one puppet character also reminds the general man that humans in the world have various characters and behaviors. This figure is so good for giving the example of life especially which has correlation with moral attitude in life in STKIP BIM.

\section{B. Imaging Value}

The term value is usually translated into Indonesian into a value and can be interpreted as a price [9]. Tracking the reality of this value can be done by observing a person's tendency to behave. In addition, if viewed from constructivism theory, according to Vygotsky, the purpose of learning is to observe activities that contain value so that learning will be achieved by learning to complete tasks that have not been studied but those tasks are still within their closest development area, namely tasks that lie above the rank of development. The moral value which can be taken from this figure is rilex, so humble, friendly with another. Espeacially about attire in STKIP BIM environment.

From various views on value classification, it is necessary to discuss instrumental and terminal values closely with character education, especially in the Bina Insan Mandiri Surabaya College of Teacher Training and Education (STKIP
BIM), because it views that human values can be demonstrated by ways of behaving or behavioral results.

\section{Value Sources developed in Character Education.}

Clara [10] suggests that Vygotsky's work was based on two main ideas. First, intellectual development can be understood only when viewed from the historical context and culture of life experience. The values developed in national character education are identified from the following sources: (a) Religion: Indonesian people are religious communities. The results of this activity will be able to grow the value of character education in themselves through various learning activities that occur in learning classes especially in the STKIP Bina Insan Mandiri Surabaya environment.

Character education originating from puppet or folklore is also developed in the curriculum to teach students about the important characteristics needed to build character. Good literature with character development themes has the power to develop, shape, and reinforce essential dispositions for instilling in many important core ethical values [11]. These are included folklore as one of the teaching materials that could be used as an alternative as a character education tool, especially if there is a correlation with the moral value in life

\section{Subjects of Character}

In principle, the development of the values of character education is one of the nation's efforts in self-development, and culture in the academic environment. The development of the value of character education is packaged in subjects of character education, which are compulsory institutions in the STKIP Bina Insan Mandiri Surabaya environment. These three processes are intended to develop the ability of students to carry out social activities as noble social beings.

\section{CONCLUSION}

From this description about meaning of Javanese puppets can be said, that the meaning of puppet does not only appear as entertainment and biographies of the ancestors, but more inclined to the meaning of life which is studied more deeply through character learning. Taken from the word learning, learning according to constructivism is active activity, where students foster their own knowledge, seek meaning from what they learn and is a process of completing new concepts and ideas with existing frameworks of thinking and possessions.

In constructing of knowledge, students are required to have a basis for how to make hypotheses and have the ability to test them, solve problems, find answers to problems they encounter, hold reflections, express ideas and ideas in order to obtain new construction. From the Javanese puppet words, some puppet figures were obtained. Among them are four clowns. The four figures of the cleric consisted of Semar and his three children, including Gareng, Petruk, and Bagong.

Based on the correlated meaning in Javanese puppets and character education in social interaction spurs the formation of new ideas and enriches the intellectual development of students. All individuals of which are packed in character education. The subject of character education is a course that 
provides more insight into values, norms, morals, and their implementation in character education especially in the STKIP Bina Insan Mandiri Surabaya environment.

\section{REFERENCES}

11] M. Tam, "Constructivism, instructional design, and technology: Implications for transforming distance learning," Educ. Technol. Soc., vol. 3, no. 2, pp. 50-60, 2000.

[2] C. Podhorsky and V. Moore, "Issues in curriculum: Improving instructional practice through lesson study," Tersedia pada http//www. lessonstudy. net, 2006.

[3] Koentjaraningrat, Javanese culture. Oxford University Press, 1990.

[4] L. J. Moleong, "Qualitative Research Methodology Revised Edition," Bandung PT Remaja Rosdakarya Offset Publ., 2013.

[5] R. K. Yin, Qualitative research from start to finish. Guilford Publications, 2015.
[6] K. E. Newcomer, H. P. Hatry, and J. S. Wholey, "Conducting semistructured interviews," Handb. Pract. Progr. Eval., vol. 492, 2015.

[7] I. Risdiyanti and R. C. I. Prahmana, "Ethnomathematics: Exploration in javanese culture," in Journal of Physics: Conference Series, 2017, vol. 943, no. 1, p. 12032.

[8] S. Pujiyanto and A. Pramono, "Punakawan' Local Character as a Creativity Idea In Designing Visual Communication,” Asian J. Soc. Sci. Humanit. Vol, vol. 6, p. 3, 2017.

[9] D. Throsby, "Determining the value of cultural goods: How much (or how little) does contingent valuation tell us?," J. Cult. Econ., vol. 27, no. 3-4, pp. 275-285, 2003.

[10] M. Clarà, "How instruction influences conceptual development: Vygotsky's theory revisited," Educ. Psychol., vol. 52, no. 1, pp. 50-62, 2017.

[11] S. Brynildssen, Character education through children's literature. ERIC Clearinghouse on Reading English and Communication, 2002. 